\title{
Kinetics of Soil L-Glutaminase Enzyme
}

\author{
G. Pavani*, P. Chandrasekhar Rao, G. Padmaja and R. Subhash Reddy \\ Department of Soil Science and Agriculture Chemistry, College of Agriculture, Professor \\ Jayashankar Telangana State Agricultural University, Rajendranagar, \\ Hyderabad - 500030, Telangana, India \\ *Corresponding author
}

\begin{tabular}{|c|c|}
\hline \multicolumn{2}{|r|}{ A B S T R A C T } \\
\hline & \multirow{5}{*}{ 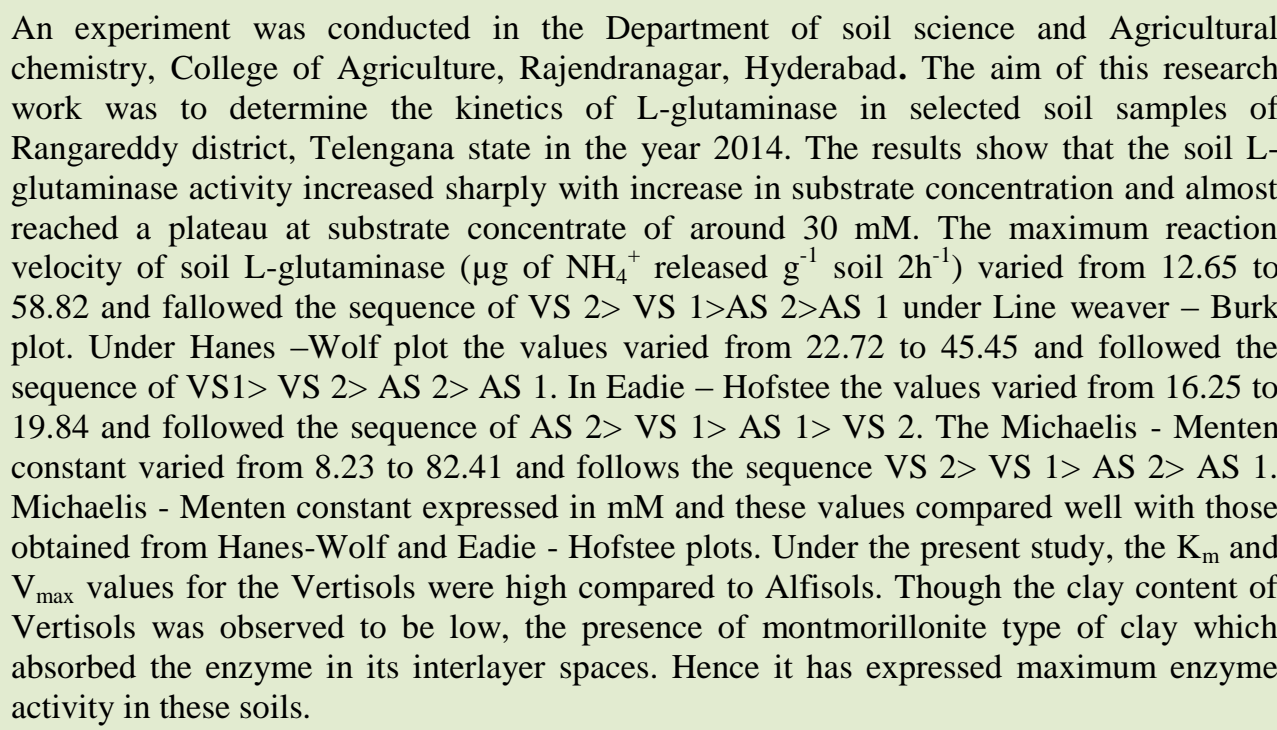 } \\
\hline Keywords & \\
\hline Article Info & \\
\hline $\begin{array}{l}\text { Accepted: } \\
\text { 10 September } 2017 \\
\text { Available Online: } \\
10 \text { October } 2017\end{array}$ & \\
\hline & \\
\hline
\end{tabular}

\section{Introduction}

L-Glutaminase enzyme was an important enzyme involved in the mineralization of amide forms of nitrogen in the soils. The characteristics of enzyme were determined by these kinetics. The two most remarkable properties of enzymes are their specificity and catalytic efficiency, and it is these properties that enzymes differ in their most strinkingly from simple catalysts. When it is possible to compare the enzymatic rates with their own non - enzymatic counterparts, one finds that enzymes enhance the reaction by several orders of magnitude. Soil enzymes are largely immobilized enzymes in soil colloidal particle and hence are different from homogeneous systems. Nevertheless, with small substrates, the rate of reaction not expected to be very much reduced as most of the diffusion mobility residues with the substrates (Mc laren, 1978). Theories and mathematical analysis of enzyme reaction are based on the concept that enzymes act by forming a 
complex or compound with substrate presumably the complex of enzyme and substrate is unstable and proceeds through one or more steps or rearrangement to form the product plus the original enzyme. This theory of enzyme was proposed by Michaelis and Menten (1913) and may be expressed by following equation:

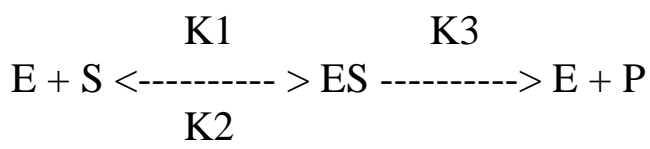

Where, $\mathrm{S}$ is the substrate, $\mathrm{E}$ is the enzyme, $\mathrm{ES}$ is the intermediate enzyme - substrate complex

$\mathrm{P}$ is the product of the reaction and $\mathrm{K}_{1}, \mathrm{~K}_{2}$ and $\mathrm{K}_{3}$ are the respective reaction velocity constants or rate constant of the three processes.

It can be shown with the soluble substrates in excess, the rate of reaction that is the decrease in concentration of the substrate with time or the increase in concentration of the product is given by:

$\frac{d s}{d t}=\frac{d p}{d t}=k_{3}[E S]=\mathrm{K}_{3}[\mathrm{ES}]=\frac{\mathrm{K}_{\mathrm{g}}[\mathrm{E}][\mathrm{s}]}{\mathrm{K}_{\mathrm{m}}+[\mathrm{s}]}=\frac{\mathrm{v}_{\operatorname{mar}}[\mathrm{s}]}{\mathrm{K}_{\mathrm{m}}+[\mathrm{s}]}$

Where $\mathrm{S}$ and ES are the concentration of substrates and enzyme- substrate complex respectively, $\mathrm{K}_{\mathrm{m}}$ is Michaelis constant.

$$
K_{m}=\frac{K_{2}+K_{\mathrm{g}}}{K_{1}}
$$

$\mathrm{V}_{\max }=\mathrm{K}_{3} \mathrm{E}(3)$

$\mathrm{K}_{\mathrm{m}}$ is equal to substrate concentration (expressed in moles per litre) at

$\mathrm{V}=\mathrm{V}_{\max } / 2$

When $\mathrm{K}_{2}$ greater than $\mathrm{K}_{3}, \mathrm{~K}_{\mathrm{m}}$ may be set equal to dissociation constant $\left(\mathrm{K}_{2} / \mathrm{K}_{1}\right)$ of enzyme - substrate complex and $1 / \mathrm{K}_{\mathrm{m}}$ then becomes the affinity constant. Although these equations are basic, it must be kept in mind $\mathrm{pH}$, ionic strength, temperature and many other factors influence the values of $\mathrm{K}_{1}, \mathrm{~K}_{2}$, $\mathrm{K}_{3}$ (Irving and Cosgrove, 1976).

For the experimental determination of $\mathrm{V}_{\max }$ and $\mathrm{K}_{\mathrm{m}}$ linear forms of the Michaelis- Menten equation are generally used.

$\frac{1}{V}=\frac{1}{V_{\max }}+\frac{K_{m}}{V_{\max }} \cdot \frac{1}{[S]} \quad$ Lineweaver - Burk transformation (4)

$\frac{[S]}{V}=\frac{K_{m}}{V_{\max }}+\frac{1}{V_{\max }} \cdot[S] \quad$ Hanes - Wolf transformation (5)

$\mathrm{V}=\mathrm{V}_{\max }-\mathrm{K}_{\mathrm{m}} \times \frac{\mathrm{v}}{[\mathrm{s}]} \quad$ Eadie $\quad-\quad$ Hofstee transformation (6)

Plots of the variables of such relationship normally give straight lines. The values of slope and intercept are commonly used for determination of constants from a set of experimental data. Once the $\mathrm{K}_{\mathrm{m}}$ and $\mathrm{V}_{\max }$ are known for a particular enzymatic reaction under a given set of conditions, the reaction velocity, $\mathrm{V}$ can be calculated for any substrate concentration. The Michaelis constant is the most fundamental constant in enzyme chemistry. It has the dimensions of concentration (that is, moles per litre) and it is constant for the enzyme only under rigidly specified conditions. The $\mathrm{K}_{\mathrm{m}}$ value is useful in estimating the substrate concentration necessary to give a maximum velocity.

Frankenberger and Tabatabai (1991b) reported that the Application of three linear transformations of the Michaelis-Menten equation showed that the $K_{m}$ values of $L$ asparaginase in nine soils ranged from 2.6 to 10.0 (average 6.1 ) $\mathrm{mM}$ and the $\mathrm{V}_{\max }$ values ranged from 9 to $131 \mathrm{ug} \mathrm{NH}_{4}{ }^{+}-\mathrm{N}$ released $\mathrm{g}^{-1}$ soil $2 \mathrm{~h}^{-1}$. Generally, the $\mathrm{K}_{\mathrm{m}}$ and $\mathrm{V}_{\max }$ values 
were consistently higher in the following order: Hanes-Woolf > Eadie-Hofsee > Lineweaver-Burk method. Frankenberger and Tabatabai (1991c) reported that the application of three linear transformations of the Michaelis-Menten equation showed that the $\mathrm{K}_{\mathrm{m}}$ values of L-glutaminase in nine soils ranged from 8.2 to $38.6(\mathrm{av}=21.7) \mathrm{mM}$ and the $\mathrm{V}_{\max }$ values ranged from 43 to $854 \mu \mathrm{g}$ $\mathrm{NH}_{4}-\mathrm{N}$ released g- ${ }^{1}$ of soil $2 \mathrm{~h}$. Zhang et al., (2010) reported that comparing with conventional tillage, no tillage increased the contents of soil total $\mathrm{C}, \mathrm{N}$, and $\mathrm{S}$ and available $\mathrm{N}$, the activities of test enzymes, and the $V_{\max } / K_{\mathrm{m}}$ of soil urease, protease, and phosphomonoesterase, but decreased the activity of soil $\alpha$-galactosidase and the $V_{\text {max }} / K_{\mathrm{m}}$ of soil $\beta$-glucosidase significantly. This was due to the long term no tillage for the maize production enhanced the soil nutrients storage and the turnover of soil $\mathrm{N}$ and P. Hojjati and Nourbakhsh (2007) reported that the maximum velocity $\left(\mathrm{V}_{\max }\right)$ values of L-glutaminase ranged from 331 to $1,389 \mathrm{mg} \mathrm{NH}_{4}{ }^{+}-\mathrm{N} \mathrm{kg}^{-1} 2 \mathrm{~h}^{-1}$. Values of the Michaelis constant $\left(\mathrm{K}_{\mathrm{m}}\right)$ ranged from 35.1 to $71.7 \mathrm{mM}$ in organically amended soils.

Organic C content of the soils were significantly correlated with $\mathrm{V}_{\max }(\mathrm{r}=0.919)$ and $\mathrm{K}_{\mathrm{m}}(\mathrm{r}=0.763)$ values. These results demonstrate the considerable influence that solid waste application has on this enzymatic reaction involved in $\mathrm{N}$ mineralization in soil. Because $V_{\max }$ values are indicative of the enzyme content in soil, the amount of enzyme in soil has increased as a result of organic amendment.

\section{Materials and Methods}

\section{Determination of $K_{m}$ and $V_{\max }$ Values}

For the determination of $\mathrm{K}_{\mathrm{m}}$ and $\mathrm{V}_{\max }$ values the enzyme activity was determined at a series of substrate concentrations.

\section{L-Glutaminase}

The studies on the effect of substrate concentration on the activity of L-glutaminase were carried out in duplicates in two Vertisols (VS 1 and VS 2) and two Alfisols (AS 1 and AS 2). To $10 \mathrm{~g}$ of soil taken in $150 \mathrm{ml}$ conical flask, $20 \mathrm{ml}$ of L-glutaminase solution varying different concentration ranging from 2, 4, 6, 8, 10, 20, 30, $40 \mathrm{mM}$ were used. These flask were incubated at $37 \pm 0.5{ }^{\circ} \mathrm{C}$ for 2 hours. After incubation, the activity of Lglutaminase was terminated by the addition of $\mathrm{KCl}-\mathrm{Ag}_{2} \mathrm{SO}_{4}$. The enzyme activity was determined by estimating the $\mathrm{NH}_{4}{ }^{+}$released by steam distillation method described in 3.2.1

\section{Calculation of $K_{m}$ and $V_{\max }$ values}

$\mathrm{K}_{\mathrm{m}}$ and $\mathrm{V}_{\max }$ values were calculated using Michaelis Menten equation, for enzyme reactions (Eqn. 1)

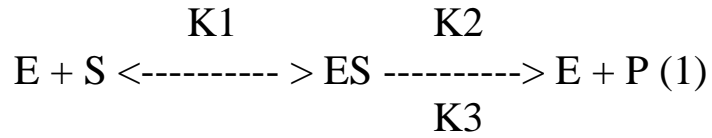

Where,

$\mathrm{S}=$ Substrate

$\mathrm{E}=$ Enzyme

$\mathrm{ES}=$ Enzyme Substrate complex

$\mathrm{P}=$ Product

$\mathrm{K} 1$, $\mathrm{K} 2$, $\mathrm{K} 3$ are velocity constants for respective steps.

$$
V=\frac{\mathrm{K}_{3}[\mathrm{E}][\mathrm{s}]}{\mathrm{K}_{\mathrm{m}}+[\mathrm{s}]}=\frac{\mathrm{v}_{\max }[\mathrm{s}]}{\mathrm{K}_{\mathrm{m}}+[\mathrm{s}]}(2)
$$

Where, 
$\mathrm{V}=$ Velocity of reaction

$\mathrm{V}_{\max }=\mathrm{K}_{3}[\mathrm{E}]$

$\mathrm{K}_{\mathrm{m}}=$ Dissociation constant of the enzyme substrate complex

The three linear forms of transformations of the above equation given below were used to determine $\mathrm{V}_{\max }$ and $\mathrm{K}_{\mathrm{m}}$.

\section{Lineweaver - Burk transformation}

$\frac{1}{V}=\frac{1}{V_{\max }}+\frac{K_{m}}{V_{\max }} \cdot \frac{1}{[S]}$

$\mathrm{V}_{\max }$ was calculated from $\frac{1}{\text { Intercept }}$ and

$\mathrm{K}_{\mathrm{m}}$ from $\frac{\text { slope }}{\text { Intercept }}$ of the plot of $\frac{1}{\mathrm{~V}}$ vs $\frac{1}{[\mathrm{~S}]}$

\section{Hanes- Wolf transformation}

$\frac{[S]}{V}=\frac{K_{m}}{V_{\max }}+\frac{1}{V_{\max }} \cdot[S]$

$\mathrm{V}_{\max }$ was obtained from $\frac{1}{\text { slope }}$ and

$\mathrm{K}_{\mathrm{m}}$ from $\frac{\text { Intercept }}{\text { slope }}$ of the plot of $\frac{[\mathrm{S}]}{\mathrm{V}}$ vs $[s]$

\section{Eadie- Hofstee transformation}

$\mathrm{V}=\mathrm{V}_{\max }-\mathrm{K}_{\mathrm{m}} \cdot \frac{\mathrm{V}}{[\mathrm{S}]}$

Plot of $\mathrm{Vs} \frac{V}{[S]}$ gave $\mathrm{V}_{\max }$ as the intercept and $\mathrm{K}_{\mathrm{m}}$ as the slope.

\section{Results and Discussion}

\section{Kinetics of soil enzymes}

The two fundamental kinetic parameters of a enzyme catalysed reaction are ' $\mathrm{V}_{\max }$ ' which corresponds to the maximum potential of enzyme present in soil and is reached when all the active sites of the enzyme are fully saturated with substrate and Michaelis Menten constant, which is an index of apparent affinity between the enzyme and its substrate and gives the substrate concentration at which reaction rate reaches half of its maximum value i.e $\mathrm{V}_{\max } / 2 . \mathrm{K}_{\mathrm{m}}$ is a measure of dissociation constant of enzyme substrate complex.

\section{$V_{\max }$ and $K_{m}$ for soil L-glutaminase}

$\mathrm{V}_{\max }$ and $\mathrm{K}_{\mathrm{m}}$ were obtained by determining the enzyme activity at a series of substrate concentration ranging from 2 to $40 \mathrm{Mm}$. A constant $\mathrm{pH}$ of 8 was maintained in all the cases with $0.1 \mathrm{M}$ THAM buffer. The soil Lglutaminase activity increased sharply with increase in substrate concentration and almost reached a plateau at substrate concentrate of around $30 \mathrm{mM}$. For all the four soils studied, with further increase in concentration of substrate a minimum increase in the enzyme activity was observed. The results are depicted in Figure 1. The $V_{\max }$ and $K_{m}$ values were determined for L-glutaminase using 3 linear transformations of Michaelis Menten equation as described under materials and methods, Lineweaver - Burk transformation plot of $1 / \mathrm{V}$ vs $1 /[\mathrm{S}$ ], Hanes-Wolf transformation plot of $[\mathrm{S}] / \mathrm{V}$ vs $[\mathrm{S}]$ and Eadie -Hofstee transformation plot of $\mathrm{V}$ vs $\mathrm{V} /[\mathrm{S}]$ for four selected soils are depicted in Figures 2,3 and 4 respectively.

From the graph it was observed with all the soils reasonably linear plots were obtained under all the 3 transformations, the values of $\mathrm{V}_{\max }$ and $\mathrm{K}_{\mathrm{m}}$ obtained from these plots are presented in Table 1.

The maximum reaction velocity of soil Lglutaminase $\left(\mu \mathrm{g}\right.$ of $\mathrm{NH}_{4}{ }^{+}$released $\mathrm{g}^{-1}$ soil $2 \mathrm{~h}^{-1}$ ) varied from 12.65 to 58.82 and fallowed the sequence of VS $2>\mathrm{VS} 1>\mathrm{AS} 2>\mathrm{AS} 1$ 
under Lineweaver - Burk plot. Under Hanes Wolf plot the values varied from 22.72 to 45.45 and followed the sequence of VS1> VS
2> AS 2> AS 1. In Eadie - Hofstee the values varied from 16.25 to 19.84 and followed the sequence of AS 2> VS 1> AS 1>VS 2.

Fig.1 Effect of Substrate Concentration on L-glutaminase activity

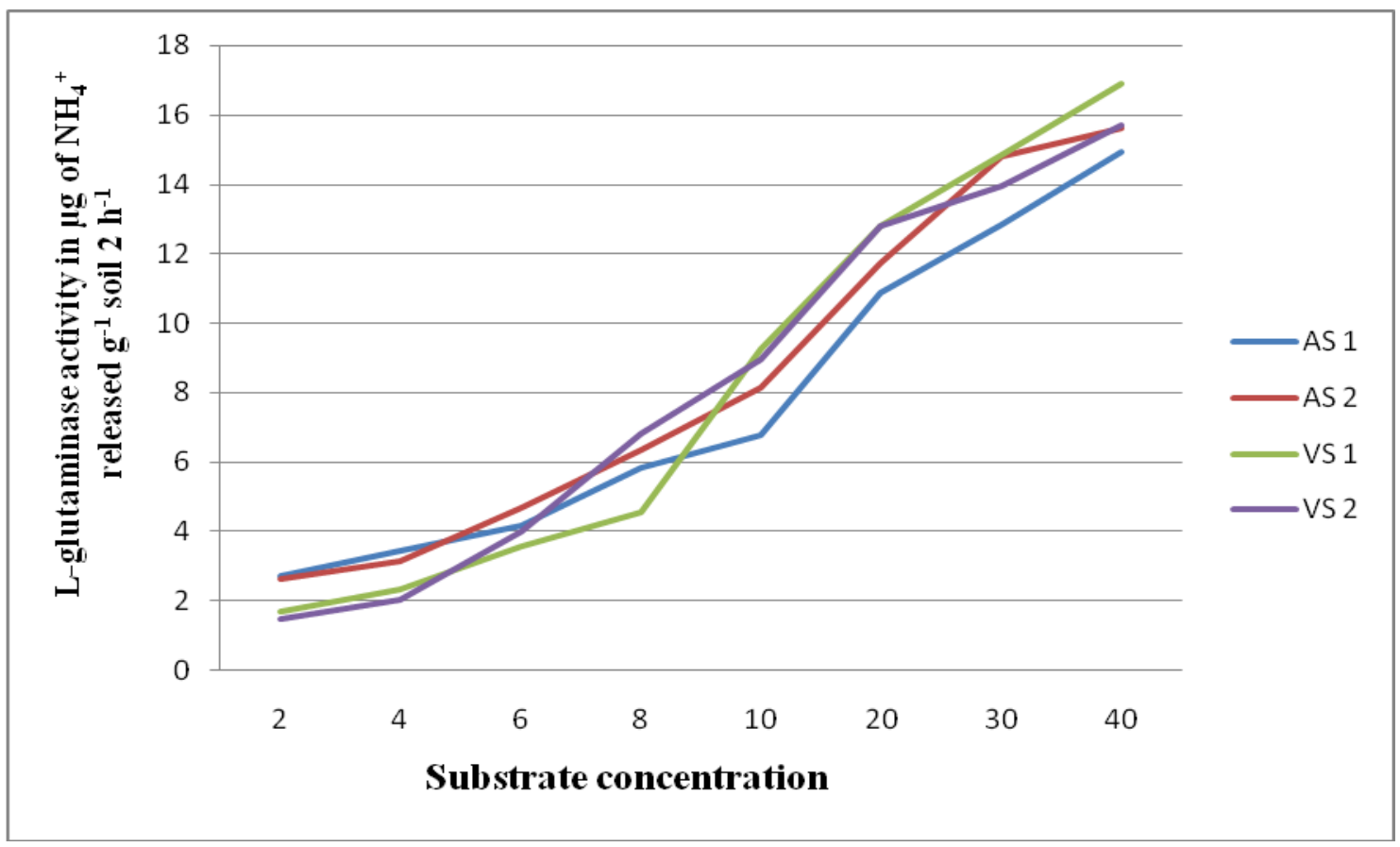

Fig.2 Lineweaver- Burk plot of soil L-glutaminase activity

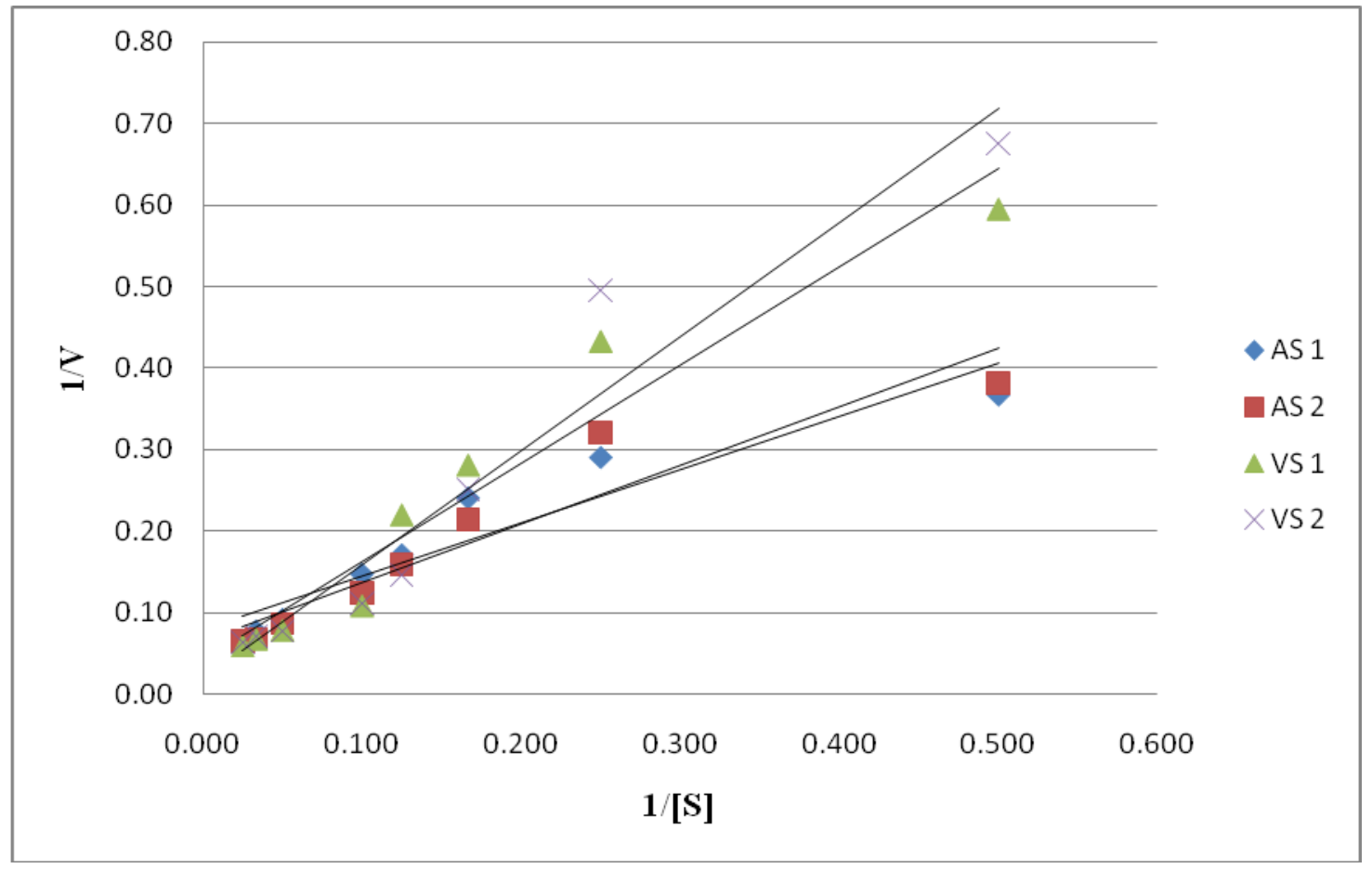


Fig.3 Hanes -Wolf plot of soil L-glutaminase activity

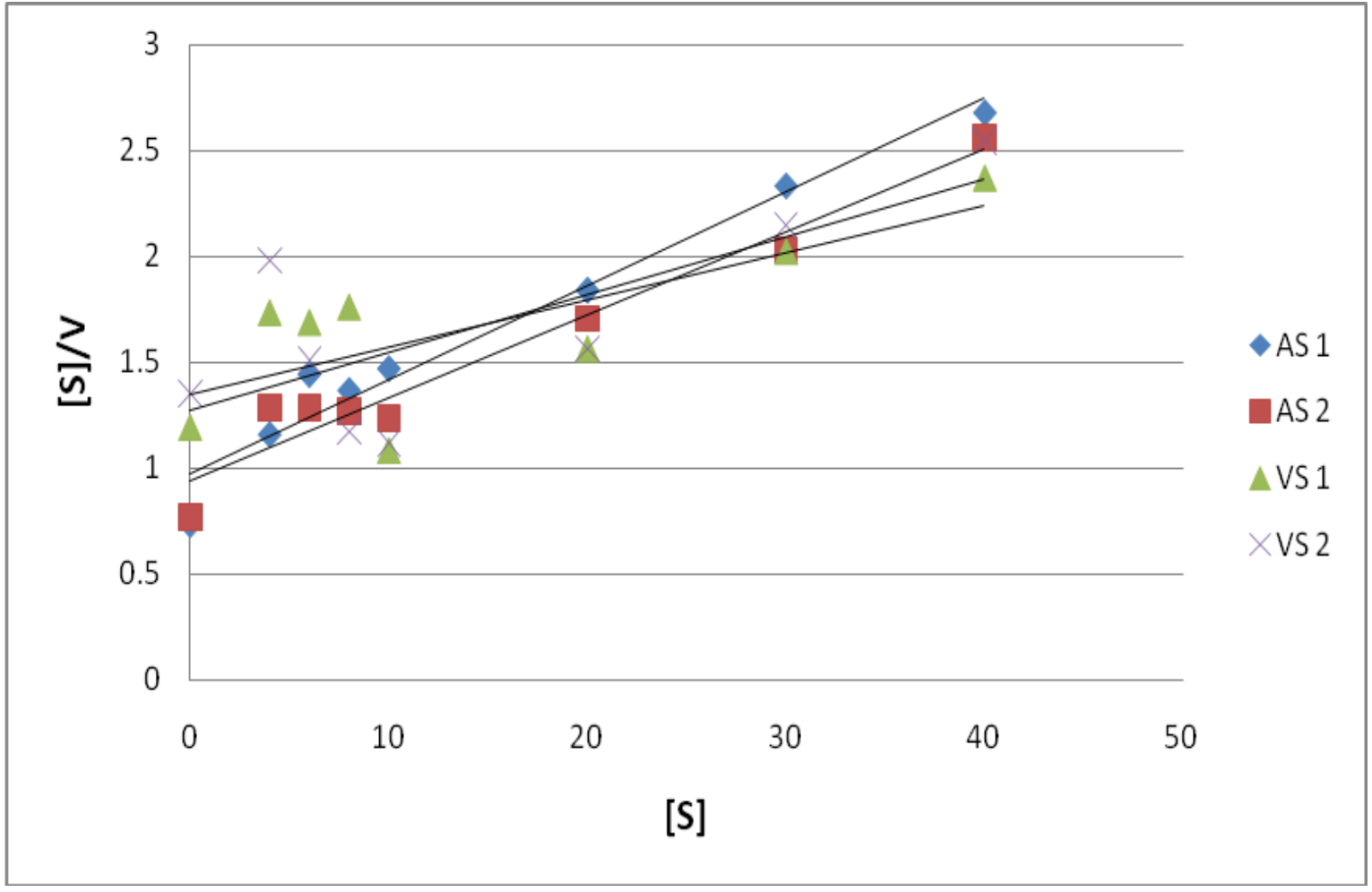

Fig.4 Eadie - Hofstee plot of soil L-glutaminase activity

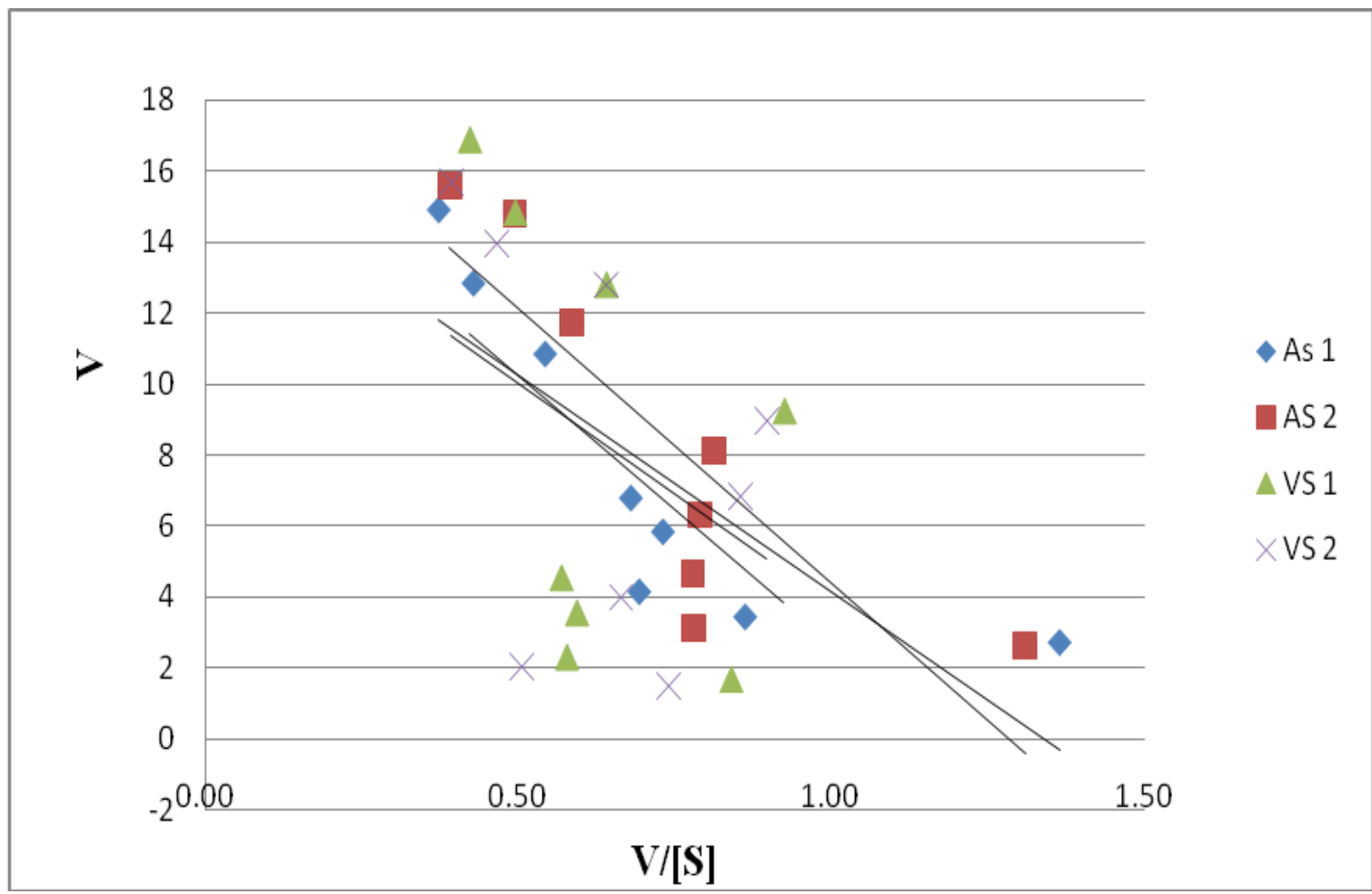


Table.1 Maximum enzyme reaction velocity $\left(\mathrm{V}_{\max }\right)$ and Michaelis-Menten constant $\left(\mathrm{K}_{\mathrm{m}}\right)$ values of soil L-glutaminase

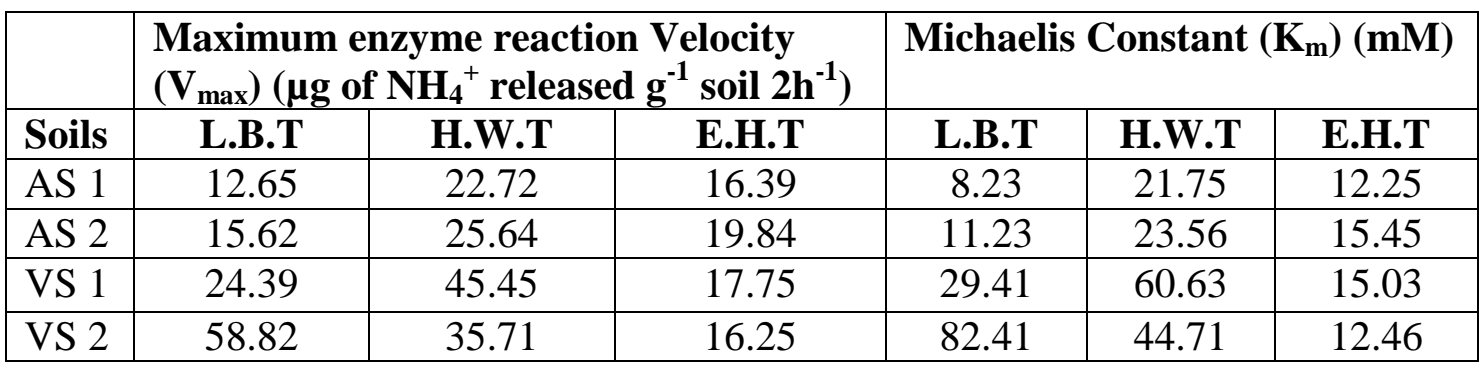

L.B.T = Lineweaver-Burk Transformation

H.W.T = Hanes - Wolf Transformation

E.H.T = Eadie- Hofstee transformation

The Michaelis - Menten constant varied from 8.23 to 82.41 and follows the sequence VS 2> VS 1> AS 2> AS 1. Michaelis - Menten constant expressed in $\mathrm{mM}$ and these values compared well with those obtained from Hanes-Wolf and Eadie - Hofstee plots. Under the present study, the $\mathrm{K}_{\mathrm{m}}$ and $\mathrm{V}_{\max }$ values for the Vertisols were high compared to Alfisols. Though the clay content of Vertisols was observed to be low, the presence of montmorillonite type of clay which absorbed the enzyme in its interlayer spaces.

Hence it has expressed maximum enzyme activity in these soils. Similar results were reported by Frankenberger and Tabatabai $(1991 b, c)$ for soil L-asparaginase and soil Lglutaminase, and by Srinivas (1993) for soil urease and Vandana (2012) for soil urease and soil phosphatase. Similar to free enzymes soil enzyme substrate affinity is increased with increase in soil moisture content because of enhanced dissolution and translocation of the substrate. The $\mathrm{K}_{\mathrm{m}}$ values obtained for $\mathrm{L}$ glutaminase were found to be higher in our soils than that obtained for this enzyme in Iowa soils $(10 \mathrm{mM})$ (Frankenberger and Tabatabai, 1991c).

The $\mathrm{K}_{\mathrm{m}}$ values depend on condition of assay like $\mathrm{pH}$ and temperature and also on the manner in which the enzyme is localised in soils, on the organic matter or clay organic matter complexes in soil system. $\mathrm{K}_{\mathrm{m}}$ values denote the dissociation constant of the enzyme substrate complex and irreversibly related to the stability of enzyme substrate complex. The higher values of $\mathrm{K}_{\mathrm{m}}$ as compared to pure enzymes are probably due to the rigid immobilization of the enzyme on the soil colloidal complex which restricts its interaction with the substrate.

Juan et al., (2010) found high $\mathrm{K}_{\mathrm{m}}$ values for soil urease than observed from other studies this is due to difference in soil physicochemical characteristics. Kujur et al., (2014) also found that forest soil (FS) had shown increased microbial activity and biomass due to higher organic matter content, and consequently exhibited higher maximum reaction velocity $\left(\mathrm{V}_{\max }\right)$ as compared to fresh mine spoil (FMS). Hojjati and Nourbakhsh (2007) reported that the maximum velocity $\left(\mathrm{V}_{\max }\right)$ values of L-glutaminase ranged from 331 to $1389 \mathrm{mg} \mathrm{NH}_{4}{ }^{+}-\mathrm{N} \mathrm{kg}^{-1} 2 \mathrm{~h}^{-1}$. Values of the Michaelis constant $\left(\mathrm{K}_{\mathrm{m}}\right)$ ranged from 35.1 to $71.7 \mathrm{mM}$ in organically amended soil.

The soil L-glutaminase activity increased sharply with increase in substrate concentration and almost reached a plateau at substrate concentrate of around $30 \mathrm{mM}$. The maximum reaction velocity of soil L- 
glutaminase $\left(\mu \mathrm{g}\right.$ of $\mathrm{NH}_{4}{ }^{+}$released g ${ }^{-1}$ soil $2 \mathrm{~h}$ $\left.{ }^{1}\right)$ varied from 12.65 to 58.82 and fallowed the sequence of VS $2>\mathrm{VS} 1>\mathrm{AS} 2>\mathrm{AS} 1$ under Lineweaver - Burk plot. Under Hanes -Wolf plot the values varied from 22.72 to 45.45 and followed the sequence of VS1> VS 2> AS 2> AS 1.

In Eadie - Hofstee the values varied from 16.25 to 19.84 and followed the sequence of AS 2> VS 1> AS 1> VS 2. The Michaelis Menten constant varied from 8.23 to 82.41 and The Michaelis - Menten constant varied from 8.23 to 82.41 and follows the sequence VS 2> VS 1> AS 2> AS 1. Michaelis - Menten constant expressed in mM and these values compared well with those obtained from Hanes-Wolf and Eadie Hofstee plots. Under the present study, the $\mathrm{K}_{\mathrm{m}}$ and $\mathrm{V}_{\max }$ values for the Vertisols were high compared to Alfisols. Though the clay content of Vertisols was observed to be low, the presence of montmorillonite type of clay which absorbed the enzyme in its interlayer spaces. Hence it has expressed maximum enzyme activity in these soils.

\section{References}

Frankenberger, W.T. Jr., and Tabatabai, M.A. 1991b. L-asparaginase activity of soils. Biology and Fertility of Soils. 11: 6-12.

Frankenberger, W.T. Jr., and Tabatabai, M.A. 1991c. L-Glutaminase activity of soils. Soil Biology \& Biochemistry. 869-874.

Hojjati, S., and Nourbakhsh, F. 2007. Effects of cow manure and sewage sludge on the activity and kinetics of L-glutaminase in soil. Biology and Fertility of Soils. 43: 491494.
Irving, G.C., and Cosgrove, D.J. 1976. The kinetics of soil acid phosphatase. Soil Biology and Biochemistry. 8: 335-340.

Juan, Y.H., Chen, L.J., Wu, Z.J., Wang, R., Sun, W.T and Zhang, Y.L. 2010. Kinetic and thermodynamic behaviours of soil urease as affected by urease inhibitors. R.C Suelo Nutr. Veg. 10(1): 1-11.

Kujur, M., and Patel, A.K. 2014. Kinetics of soil enzyme activities under different ecosystems: An index of soil quality. Chilean Journal of Agricultural Research. 74(1): January-March.

Mc Laren, A.D., 1978. Kinetics and consecutive reactions of soil enzymes. In Burns, R.G (eds.) - Soil enzymes. Academic Press, London. 97-116.

Michaelis, L., Menten, M.L. 1913. Biochem. Z. 49: 333-369. Nomenclature Committee of the International Union of Biochemistry (NC-IUB) 1982. Symbolism and terminology in enzyme kinetics. European Journal of Biochemistry. 128: 281-291.

Srinivas, D., 1993. Phosphomonoesterase activity in some soils of Andhra Pradesh. Distribution, kinetics and variation due to plant cover, pesticide application and submergence. Ph D Thesis. Acharya N G Ranga Agricultural University, Hyderabad.

Vandana, L.J., 2012. Urease and Phosphomonoesterase activities in soiltheir distribution kinetics and influence of management practices on their activity. $P h$ $D$ Thesis. Acharya N G Ranga Agricultural University, Hyderabad.

Zhang, Y.L., Chen, L.J., Chen, Z.H., Sun, C.X., Wu, Z. J and Tang, X.H. 2010. Soil nutrient contents and enzymatic characteristics as affected by 7 - year no tillage under maize cropping in a meadow brown soil. R.C. Suelo Nutr. Veg. 10(2):150-157.

\section{How to cite this article:}

Pavani, G., P. Chandrasekhar Rao, G. Padmaja and Subhash Reddy, R. 2017. Kinetics of Soil L-Glutaminase Enzyme. Int.J.Curr.Microbiol.App.Sci. 6(10): 978-985.

doi: https://doi.org/10.20546/ijcmas.2017.610.118 